\title{
AIDS bill wins overwhelming Congressional support
}

\section{Washington}

AFTER almost two years of disagreements, debates and compromises the US House of Representatives last week finally passed its first major bill designed to help stop the spread of AIDS. Only a handful of conservative Republicans offered opposition to the boosting of AIDS research, testing and counselling.

Moves are already under way to join the bill with a separate bill, passed by the Senate in April, that gives top emphasis to AIDS education. The resulting comprehensive measure has a good chance of going to the White House for signing before Congress adjourns in early October. Although the Reagan administration has opposed the bill, the strength of Congressional support makes a presidential veto unlikely.

The bill sets a precedent in requiring the federal agencies involved in research on AIDS and the development and review of AIDS drugs to hire more staff. A total of 780 new posts are provided with the major beneficiaries certain to be the National Institutes of Health, the Centers for Disease Control and the Food and Drug Administration. Increased priority is given to AIDS research by requirements that research grants be reviewed within six months of the closing date for applications, and that requests from federal agencies for personnel and facilities be answered within 14 days.

Delays in licensing new drugs have been a major source of Congressional concern. Under a last-minute amendment, added by the bill's principal sponsor Henry Waxman (Democrat, California), experimental drugs will become more easily available to people with AIDS. Medical practitioners will be permitted to prescribe experimental drugs for AIDS sufferers, provided the manufacturer has gained an exemption for investigational use of the drug. At present, access to such drugs is controlled by clinical protocols. A further relaxation of the regulations is likely in the future with legislation under discussion that would allow terminally ill people free access to unapproved drugs once they are determined to be safe.

A series of measures aims at speeding up research. One sets up an international data bank at the National Library of Medicine. Another provides for the development of an epidemiological data base at the Centers for Disease Control. All states that receive money under the bill are required to collect demographic information about those who test positive for the AIDS virus.

The most controversial section of the bill provides $\$ 400$ million a year for testing and pre- and post-test counselling of people who have a high risk of exposure to the HIV virus. Differences of opinion centred around the need for compulsory testing and the confidentiality of test results. Conservatives, led by William Dannemeyer (Republican, California), backed a series of amendments that would have forced testing of all 550,000 members of the US prison population, all those applying for marriage licences, and those entering hospital. But the three amendments were rejected on the grounds that

\section{Biological warfare lab dropped}

\section{Washington}

YIELDING to pressure from local residents and anti-biotechnology activist Jeremy Rifkin, the US army last week announced that it will drop its plans to build a highcontainment weapons laboratory at its Dugway Proving Ground in Utah. Instead the army intends to construct a less sophisticated facility that would not be suitable for testing the microbes which most worry opponents: genetically engineered microbes and those which cause incurable diseases.

The army has contended that the tests it plans to conduct at the Dugway facility do not require the highest containment level, biosafety level 4 (BL-4), but that it would prefer to build such a facility in case its needs change, and as an added degree of safety. It played down the option of building a lower-containment biosafety level 3 (BL-3) laboratory on these grounds in the environmental impact statement on its biological defence activities. That impact statement was produced as a result of a lawsuit brought by Rifkin in 1985 (see Nature 331, 647; 1988).

Ironically, lowering the safety designation of the laboratory is not likely to get the army off the hook. Grassroots opposition to building any sort of biological warfare test facilities at Dugway is strong, and is being coordinated at the Federal level by Rifkin. Rifkin says he will pressure the army to prepare another full environmental impact statement on the BL-3 laboratory - a process that could delay construction for two more years - and that if the army "so much as lays one brick" he will petition the courts for an injunction. But officials at Dugway say that they only intend to "expand the discussion of (a BL-3 laboratory) as the preferred alternative" in the original environmental impact statement, and that they will include costs for the laboratory in Dugway's budget request to Congress beginning in 1991. Carol Ezzell they would cost a lot but yield little useful result. Pre-marriage tests were particularly criticized because of the damage that can be done by false-positive results. But prisoners at high risk will be tested for the HIV virus under a separate amendment to the bill.

Dannemeyer also introduced an amendment that would require the names of those testing positive to be recorded and their contacts traced. But the majority view was that anonymity must be protected in order that the maximum number of people at risk come forward for testing. Statistics from Oregon were cited showing that the number of prostitutes and homosexual men seeking tests rose rapidly after state requirements that their names be reported were eliminated.

Alun Anderson

- While conservative Republican Congressman William Dannemeyer did not win support for his views in the House of Representatives, he may do better in his home state of California. Voters in California currently appear to favour a state-wide proposition, sponsored by Dannemeyer, that would require doctors, blood banks and others to report to local health officials the names of HIV-positive individuals. The initiative, similar in style to Dannemeyer-sponsored amendments rejected by Congress, also calls for the tracing of all sexual contacts who may have contracted HIV.

Because it would require the reporting of HIV-infected patients participating in research projects, opponents say the initiative would paralyse research into potential AIDS drugs and vaccines. The cost to the state for reporting and partner-tracing was projected by two professors in the UC Berkeley School of Public Policy to exceed $\$ 772$ million.

The initiative, called Proposition 102, is slated for a vote in November. Its cosponsor is Paul Gann, a former state legislator best known for leading the California tax-revolt, who contracted AIDS through a blood transfusion. It is the third proposition of its kind to come before California voters. In November 1986 and June 1988, voters rejected initiatives, backed by supporters of right-wing extremist Lyndon LaRouche, which called for the reporting and quarantine of HIV-infected people.

Despite the defeat of the initiative in June, a poll in late July showed 72 per cent of voters in favour of Proposition 102, when it was described to them simply as an initiative to require the reporting to local health officials of the names of people infected with HIV. Opponents of the proposition - who include all Californian medical associations - are relying on an information campaign to change voters' minds. Polls show that support for the proposition vanishes when voters are told of its potential cost and consequences. 